\title{
Invertase and Disulphide Bridges in the Yeast Wall
}

\author{
By D. K. KIDBY* AND R. DAVIES \\ Sub-Department of Chemical Microbiology, \\ Department of Biochemistry, University of Cambridge, Cambridge
}

(Accepted for publication 13 February 1970)

\section{SUMMARY}

Invertase released from Saccharomyces fragilis (Jorgensen) by either breakage or thiol treatment exhibited identical electrophoretic characteristics. Evidence was obtained against an indirect chemical effect of breakage on the release of invertase from yeasts. Electron microscopy revealed no obvious differences between walls of $S$. fragilis and other yeasts. A model is proposed in which invertase is not bonded to the wall but is retained by structures requiring intact $S-S$ linkings.

\section{INTRODUCTION}

There is no reason to doubt that yeast invertase is mainly associated with the wall (Myrback, 1960). However, opinion differs on whether or not this enzyme is associated with the wall by chemical bonds or is simply contained by a permeability barrier. The former view has been most recently expressed in a model for the yeast wall (Lampen, 1968) in which either a covalent linkage to the wall phosphomannan components is affected via the mannan moiety of the enzyme or other non-covalent bonds hold the enzyme in place. The latter view (Burger, Bacon \& Bacon, 196I) is founded upon the readiness with which the enzyme is released by breakage but retained in ethyl acetatetreated organisms (Burger, Bacon \& Bacon, 1958).

This paper describes results relevant to the elucidation of the nature of the association of invertase with the yeast wall. The observations of other workers, which have not previously been clearly related to this question, are considered. A model for the yeast wall (Kidby \& Davies, I968) is discussed.

\section{MATERIALS AND METHODS}

Yeasts. Saccharomyces fragilis (Jorgensen) was grown as previously described (Kidby \& Davies, I970). Saccharomyces cerevisiae was obtained as compressed baker's yeast from C. Holland \& Sons, Cambridge, and Sigma Chemical Co., St Louis, Mo., U.S.A., but essentially the same results were obtained for yeasts from both of these sources.

Electrophoresis. Invertase was released by treating suspensions with $5 \mathrm{mM}-2$-mercaptoethanol at $\mathrm{pH} 8.0$ for $30 \mathrm{~min}$. at $30^{\circ}$, which released $88 \%$ of the total enzyme; or by treatment in a sonic oscillator at a $500 \mathrm{~W}$ input for $60 \mathrm{sec}$. at $10^{\circ}$, which released $84 \%$ of the total enzyme. Suspensions were then centrifuged at $4^{\circ}$ and $40 \mu 1$. samples of

\footnotetext{
* Present address: Department of Microbiology, University of Guelph, Guelph, Ontario, Canada.
} 
supernatant fractions, diluted with an equal volume of a $10 \%(w / v)$ solution of mannitol in the electrophoresis buffer, were applied to $5.2 \%(w / w)$ polyacrylamide gel (Cyanogum 4I, British Drug Houses, Poole, Dorset) columns. The samples were electrophoresed in a discontinuous buffer system containing $0.3 \mathrm{M}$-boric acid, adjusted to $\mathrm{pH} 7.0$ with sodium hydroxide, in the cathode tank; and $0.05 \mathrm{M}$-tris buffer, adjusted to $\mathrm{pH} 7.5$ with citric acid, in the anode tank. A potential of $170 \mathrm{~V}$ was applied for $2.5 \mathrm{hr}$ to obtain a substantial migration of the enzyme $(c .6 \mathrm{~cm}$.). The gels were then extruded and sectioned into $0.2 \mathrm{~cm}$. fractions, which were eluted by shaking overnight in $\mathrm{I} \cdot 0 \mathrm{ml}$. of $0.2 \mathrm{M}$-acetate buffer $(\mathrm{pH} 5.0)$. The eluants were assayed for invertase activity by the method described previously (Kidby \& Davies, 1970).

Preparation of disrupted and untreated mixtures of organisms. A $0.6 \%$ and $0.4 \%$ (dry wt) suspension of Saccharomyces cerevisiae and $S$. fragilis respectively were treated in a sonic oscillator at a $130 \mathrm{~W}$ input for $5 \mathrm{~min}$. at $10^{\circ}$. This treatment released 36 and $43 \%$ of the invertase respectively but broke very few organisms. Supernatant and sedimented fractions were obtained by centrifugation at $30,000 \mathrm{~g}$ for $30 \mathrm{~min}$. at $4^{\circ}$. Equal volumes of the unfractionated treated organisms, the supernatant from fractionated treated organisms, or the resuspended sediment from treated organisms were incubated with untreated organisms of each species at either 4 or $30^{\circ}$ for $30 \mathrm{~min}$. Following incubation the total invertase released was determined in yeast-free filtrates as previously described (Kidby \& Davies, 1970). Single components of the above mixtures were also incubated to calculate the quantity of invertase released from the untreated organisms by the treated organisms.

Electron microscopy. Material for sectioning was fixed according to the Glauert \& Thornley (1966) modification of the Ryter-Kellenberger technique and embedded in Epon (Kidby \& Goodchild, 1966), except that prefixation with glutaraldehyde was omitted for half of the material sampled. This omission appeared to yield a better definition of intracellular detail but this distinction was not critically examined. Negatively stained material was first treated in a sonic oscillator at a $500 \mathrm{~W}$ input for $60 \mathrm{sec}$. at $10^{\circ}$. The disrupted yeasts were washed with $0^{\circ} \mathrm{I} \mathrm{M}$-sodium chloride three times, then once in deionized water. The sediment was resuspended in $0.2 \%(\mathrm{w} / \mathrm{v})$ phosphotungstic acid, neutralized to $\mathrm{pH} 7.0$ with $\mathrm{KOH}$, and samples dried on to grids.

Specimens were photographed at a magnification of $\times 4000$ using $35 \mathrm{~mm}$. film on a Philips EM 75 microscope.

\section{RESULTS}

The electrophoretic mobilities of invertase released by either disruption or thiol treatment were identical (Fig. r.) Recoveries of enzyme activity from each gel were also identical. A low mobility system in which the enzyme was electrophoresed in a cationic form also yielded identical mobilities but as the mobilities were extremely low, this was not acceptable as convincing evidence of similarity.

The single activity peak encountered on electrophoresis of these samples was repeatable when the enzyme was electrophoresed within a day or two of preparation. Storage of unfrozen enzyme for longer periods produced electrophoretically distinguishable species. Purification did not seem to overcome this problem as the fractionation procedures themselves appeared to induce heterogeneity (D. K. Kidby, unpublished).

Yeast which had been mechanically disrupted did not release invertase from either untreated Saccharomyces cerevisiae or S. fragilis, when incubated with these for $30 \mathrm{~min}$. at either 4 or $30^{\circ}$. 
The sectioned yeasts revealed walls of variable thickness but examples of thin-walled yeasts (Pl. I, fig. I) were rare. The pronounced convolutions at the inner margin of the wall were common but were characteristic of thick rather than thin walls (Pl. I, fig. 2). Yeasts which had been subjected to sonic oscillation for short periods frequently exhibited large tears but the walls retained considerable structural integrity, as indi-

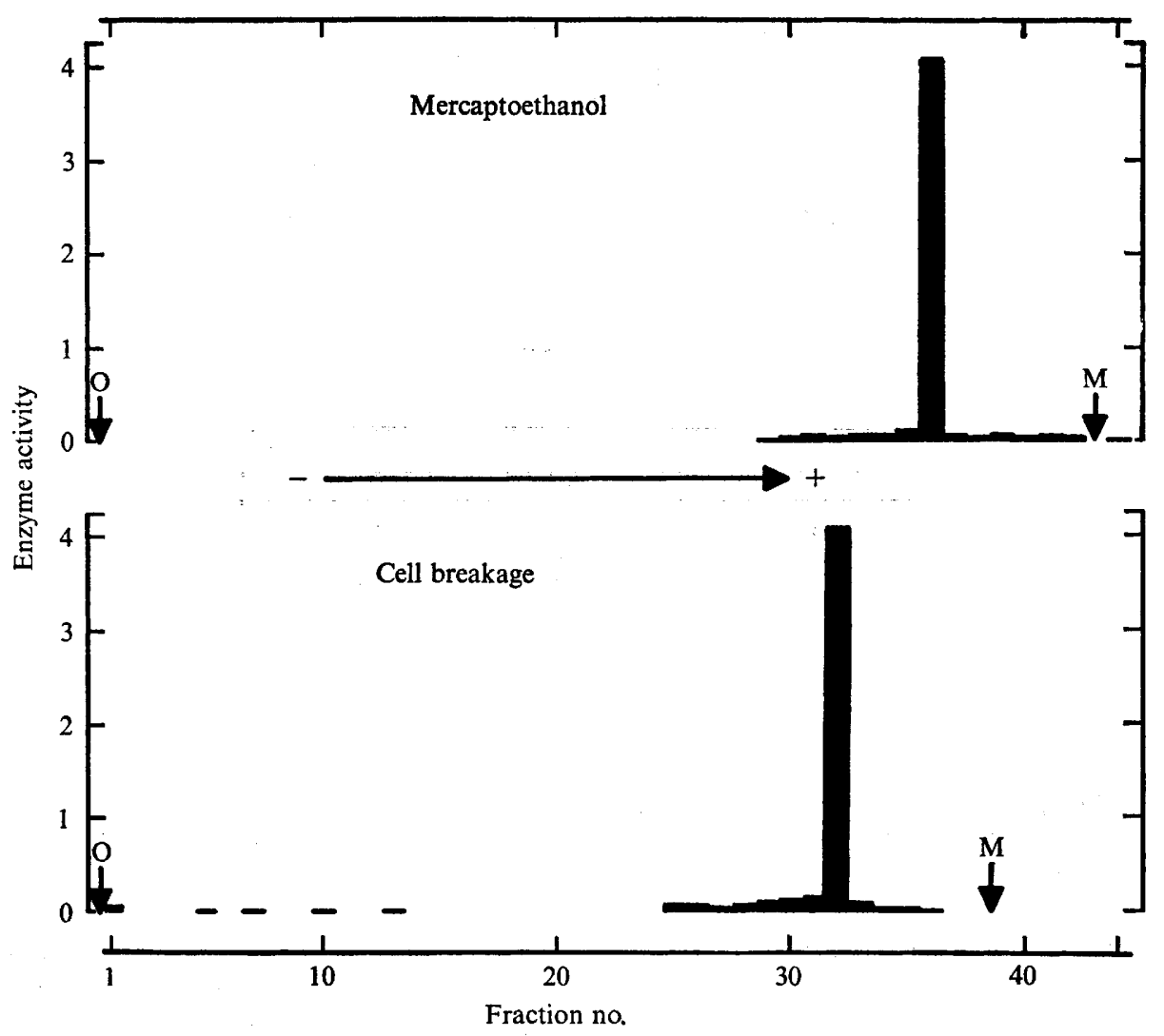

Fig. I. Electrophoretic mobility of invertase released by either mercaptoethanol or cell breakage. O, Origin; M, position of anionic marker dye (bromophenol blue); Fraction, eluant from $0.2 \mathrm{~cm}$. lengths of gel; Enzyme activity, $\mu$ moles reducing sugar produced/assay tube.

cated by retention of shape (PI. I, fig. 3), The majority remained unbroken, as indicated by retention of cytoplasmic contents, even though most of the invertase was released.

\section{DISCUSSION}

The equivalent electrophoretic mobilities of invertase released by either thiol treatment or by sonic disruption indicate that the release mechanism is essentially equivalent in each case. If, for example, there is a covalent linkage between the enzyme and the wall, then the same linkage would appear to be broken by both thiol treatment and by sonic disruption. While this possibility cannot be rejected, it would be a remarkable coincidence. 


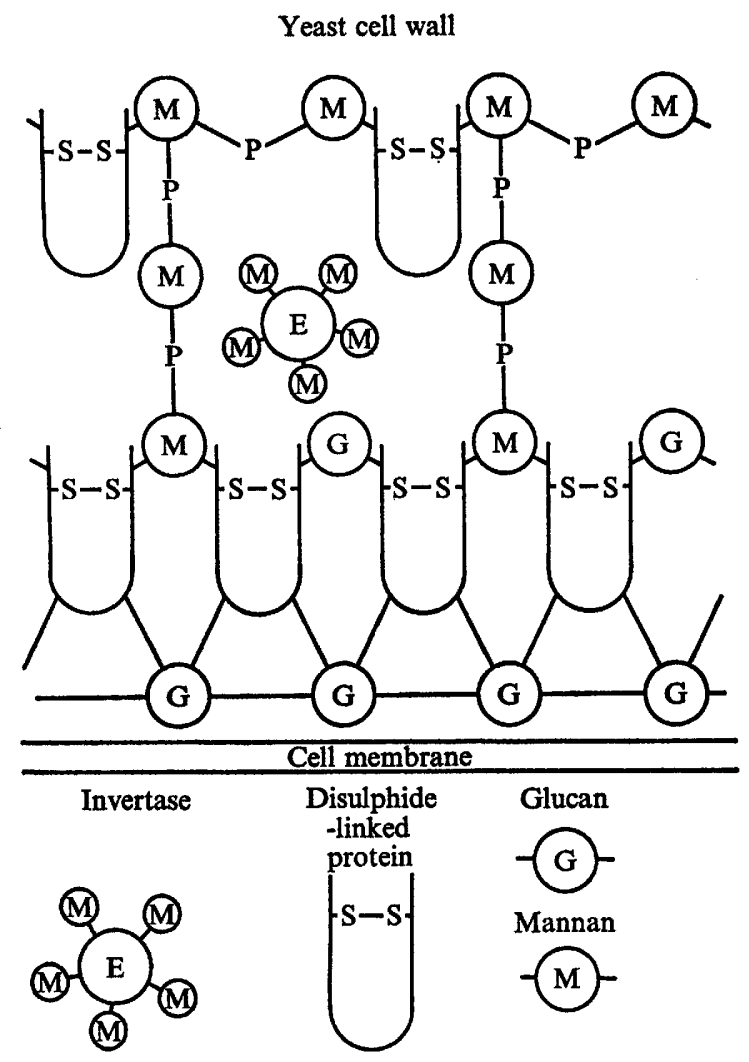

Fig. 2. A model for the yeast cell wall. The inner region of the wall is identified by the adjacent cell membrane. - P-, Phosphodiester link; other essential features are identified at the foot of the figure.

Invertase release resulting from the action of a chemical factor released by either mechanical disruption or thiol treatment was considered as a possible explanation for the apparent similarity between the release mechanisms. However, the failure of disrupted yeasts to release invertase from untreated yeasts is evidence against release of a chemical factor.

Sectioned Saccharomyces fragilis reveals features similar to those of other yeasts (Phaff, 1963). The wall region was not obviously different from that of $S$. cerevisiae (Agar \& Douglas, 1955) or Schizosaccharomyces octosporus (Conti \& Naylor, 1959). The walls varied in thickness but no more than those of $S$. cerevisiae (R. Sentandreu, personal communication). It therefore appears that neither the fragility nor the susceptibility to thiols (Davies, I966) of $S$. fragilis can be attributed to thin walls.

The retention of a high molecular weight invertase in Neurospora is correlated with wall permeability (Trevithick \& Metzenberg, I966; Trevithick, Metzenberg \& Costello, 1966) and suggests that an impermeable wall structure may be an effective barrier. It may therefore be unnecessary to invoke wall-to-enzyme bonds, as is suggested by Lampen (I968), for retention of wall enzymes. The operation of a permeability barrier is also supported by the suggested release mechanism of invertase from thiol-treated cells of Saccharomyces fragilis (Kidby \& Davies, 1970). The thiol- and KCl-induced 
invertase release from yeasts, observed by Weimberg \& Orton (1966), is difficult to interpret but is possibly a related phenomenon. Studies on the digestion of yeast wall have frequently employed thiols to sensitize the wall to the attacking enzyme. Davies \& Elvin (1964) showed that the thiol acted upon the wall rather than enhanced the activity of the digesting enzyme. Bacon, Milne, Taylor \& Webley (1965) established that thiol treatment rendered regions of the wall containing mannose and glucose more susceptible to enzyme digestion. The simplest interpretation of this is that greater quantities of the substrate are physically accessible to the enzyme. This explanation is supported by the observation that autoclaving yeasts also enhanced enzyme attack (Bacon et al. 1965).

The foregoing considerations together with the model for the yeast wall proposed by Lampen (1968) led to the proposal of a modified model (Kidby \& Davies, 1968). The major modifications contained in this model (Fig. 2) are: (i) an invertase not chemically bonded to the wall, in accordance with our own observations and those of Burger et al. (1961); and (ii) an external region in the wall which depends upon disulphide bridges for maintenance of its structural integrity as a permeability barrier to large molecules. The distribution of these disulphide bridges between inter- and intramolecular linkages is unknown and the model does not elucidate this question. The phosphodiester linkages are retained in accordance with the model of Lampen (1968), as are other features of the model. Observations on the degradation of walls by enzymes have led to the suggestion of a 'third membrane' (Bacon et al. 1965). However, provided a system exists to maintain disulphide bridges in either the oxidized or reduced state, according to physiological demand (see Nickerson, 1963), there is no reason to invoke a third membrane.

Because invertase is not released from Saccharomyces cerevisiae (Davies, 1966) it might be argued that the assumptions upon which the current model is based do not apply generally. However, thiols increase the accessibility of underlying regions of the wall of S. cerevisiae to enzyme attack (Bacon et al. 1965) and there is independent evidence for the invertase of $S$. cerevisiae being not bonded to the wall (Burger et al. 196I). Furthermore, there is evidence to suggest that the $S$. fragilis invertase escapes more readily than that of $S$. cerevisiae because the enzyme molecule is smaller. The electrophoretic mobility of the $S$. fragilis extracellular enzyme approximates the high mobility intracellular low molecular weight enzyme described by Gascon, Neumann \& Lampen (1968). The $S$. fragilis invertase also differs from invertase of other yeasts in its substrate specificity (Snyder \& Phaff, 1960).

Disulphide bridges in the outer regions of the wall and free invertase confined by a permeability barrier provide a basis for explaining all of the previously observed effects of thiols on yeast walls. It is conceivable that retention of extracellular enzymes by an impermeable wall is not peculiar to yeasts; the evidence that wall permeability is involved in Neurospora was mentioned earlier. Bacterial walls also offer similar possibilities since wall permeability (Mitchell, 1959; Gerhardt \& Judge, 1964) appears to be limiting for particles of protein size. The release of surface enzymes from bacteria (Heppel, 1967; Neu \& Chou, 1967; Rogers, 1968) may reflect wall impermeability. The concept of the wall as a molecular sieve has been suggested by Payne \& Gilvarg (1968) on the basis of differential permeation of peptides in Escherichia coli.

The extent to which disulphide bridging may contribute to such impermeability is conjectural but this appears to be a possibility in cases where wall protein layers form 
effective barriers (Weinbaum, Rich \& Fischman, 1967) or where thiols facilitate the release of protein from a wall (Sargent, Ghosh \& Lampen, 1968).

The helpful comments of Dr R. Sentandreu and Dr D. H. Northcote are gratefully acknowledged. One of us (D.K.K.) is indebted to the Commonwealth Scientific and Industrial Research Organization of Australia for a post-doctoral studentship, and to Professor E. F. Gale, F.R.S., for support and research facilities.

\section{REFERENCES}

AGAR, H. D. \& Douglas, H. C. (1955). Study of budding and cell wall structure of yeast. Journal of Bacteriology 70, 427-434.

Bacon, J. S. D., MinNe, B. D., Taylor, I. F. \& Webley, D. M. (1965). Features of the cell wall structure of yeast revealed by the action of enzymes from a non-fruiting Myxobacterium (Cytophaga johnsonii). Biochemical Journal 95, $28 \mathrm{C}$.

BURGer, M., BACON, E. E. \& BACON, J. S. D. (1958). Liberation of invertase from disintegrated yeast cells. Nature, London 182, 1508.

BURGer, M., Bacon, E. E. \& BACON, J. S. D. (1961). Some observations on the form and location of invertase in the yeast cell wall. Biochemical Journal 78, 504-5I I.

CoNT, S. F. \& NAYLOR, H. B. (1959). Electron microscopy of ultrathin sections of Schizosaccharomyces octosporus. I. Cell division. Journal of Bacteriology 78, 868-877.

DAvIES, R. (1966). Mercaptoethanol and protoplast formation and invertase release from Saccharomyces fragilis and other yeasts. In Symposium on Yeast Protoplasts. Abhandlungen der Deutschen Akademie der Wissenschaften zu Berlin, nr. 6, pp. 195-198 and 381-382. Edited by R. Müller. Berlin: Akademie-Verlag.

Davies, R. \& Exvin, P. A. (1964). The effect of $\beta$-mercaptoethanol on release of invertase and formation of protoplasts of Saccharomyces fragilis. Biochemical Journal 93, 8P.

Gascon, S., NeumanN, N. P. \& Lampen, J. O. (1968). Comparative study of the properties of the purified internal and external invertases from yeast. Journal of Biological Chemistry 243, 15731577.

Gerhardi, P. \& JUdGe, J. A. (1964). Porosity of isolated cell walls of Saccharomyces cerevisiae and Bacillus megaterium. Journal of Bacteriology 87, 945-951.

GlauerT, A. M. \& ThORNLeY, M. J. (1966). Glutaraldehyde fixation of Gram-negative bacteria. Journal of the Royal Microscopical Society 85, 449-453.

Heppel, L. A. (1967). Selective release of enzymes from bacteria. Science, New York 158, 1451-1455.

KIDBY, D. K. \& DAVIES, R. (1968). Thiol-disulphide interaction in yeast cell wall. Journal of General Microbiology 53, v.

KIDBY, D. K. \& DAVIES, R. (1970). Thiol-induced release of invertase from cell walls of Saccharomyces fragilis. Biochimica et Biophysica Acta 201, 261-266.

KIDBY, D. K. \& GOODCHIID, D. J. (1966). Host influence on the ultrastructure of root nodules of Lupinus luteus and Ornithopus sativus. Journal of General Microbiology 45, 147-152.

LAMPEN, J. O. (1968). External enzymes of yeast: their nature and formation. Antonie van Leeuwenhoek $34, \mathrm{I}-\mathrm{I} 8$.

MrtchelL, P. (1959). Biochemical cytology of micro-organisms. Annual Review of Microbiology 13, 407-440.

MyrbaCK, K. (1960). Invertases. In The Enzymes, vol. IV, pp. 379-396. Edited by P. D. Boyer, H. Lardy \& K. Myrback. New York: Academic Press.

NeU, H. C. \& CHOU, J. (1967). Release of surface enzymes in Enterobacteriaceae by osmotic shock. Journal of Bacteriology 94, 1934-1945.

Nickerson, V. J. (1963). Symposium on biochemical bases of morphogenesis in fungi. IV. Molecular bases of form in yeasts. Bacteriological Reviews 27, 305-324.

PAYNE, J. W. \& GILVARG, C. (1968). Size restriction on peptide utilization in Escherichia coli. Journal of Biological Chemistry 243, 6291-6299.

Phaff, H. J. (1963). Cell wall of yeasts. Annual Review of Microbiology 17, 15-30.

RoGers, D. (1968). Osmotic pools in Escherichia coll. Science, New York 159, 531-532. 
Journal of General Microbiology, Vol. 6I, No. 3

Plate I
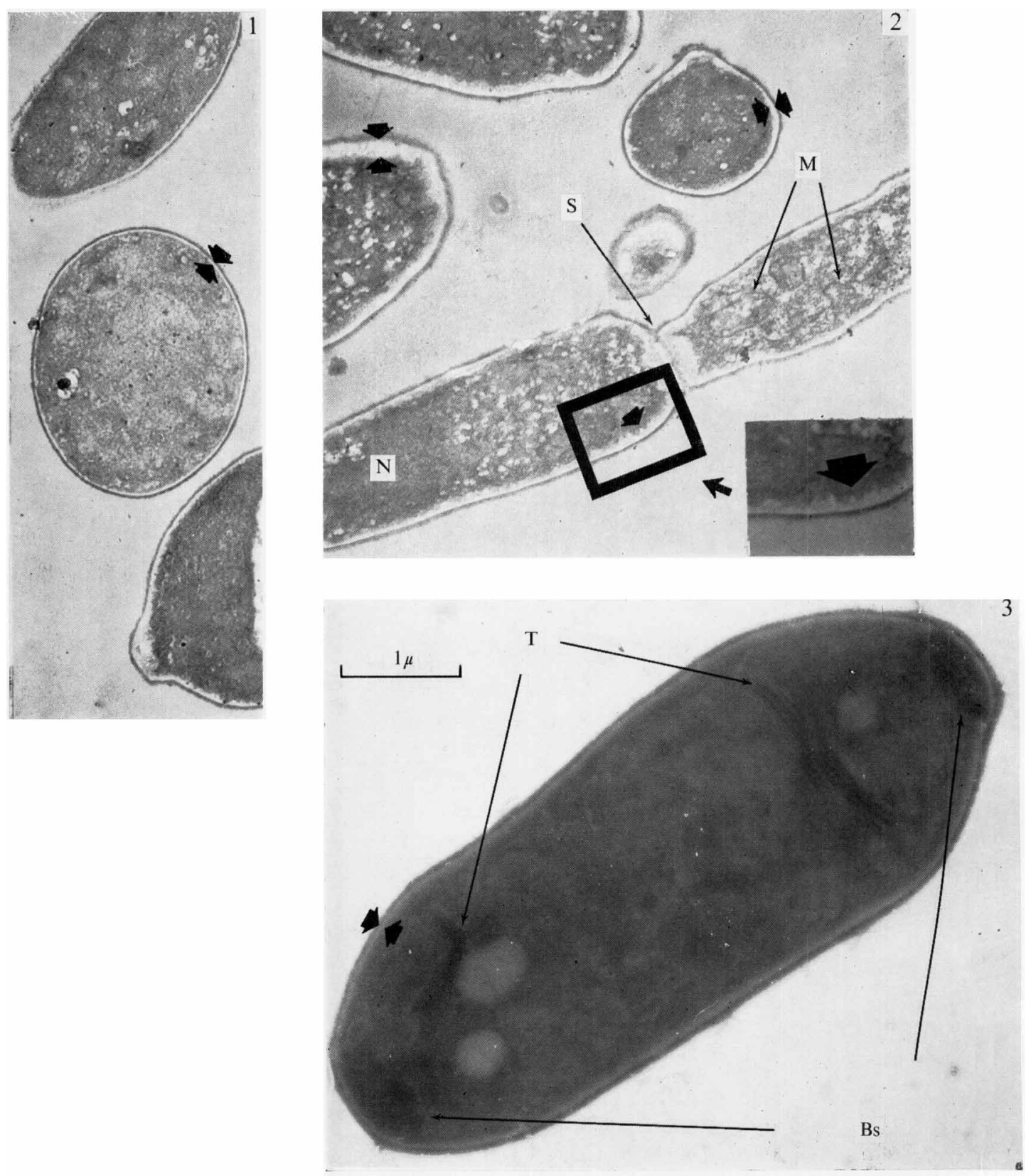

D. K. KIDBY AND R. DAVIES

(Facing p. 333) 
SARGENT, M. S., GHOSH, B. K. \& LAMPEN, J. O. (1968). Characteristics of penicillinase release by washed cells of Bacillus licheniformis. Journal of Bacteriology 96, 1231-1239.

SNYDER, H. E. \& PhafF, H. J. (1960). Studies on a $\beta$-fructosidase (inulinase) produced by Saccharomyces fragilis. Antonie van Leeuwenhoek 26, 433-452.

Trevithick, J. R. \& MetzenBerg, R. L. (I966). Molecular sieving by Neurospora cell walls during secretion of invertase isozymes. Journal of Bacteriology 92, 1010-1015.

Trevithick, J. R., Metzenberg, R. L. \& Costello, D. F. (I966). Genetic alteration of pore size and other properties of the Neurospora cell wall. Journal of Bacteriology 92, 1016-1020.

WeImBerg, R. \& ORTON, W. L. (1966). Elution of exocellular enzymes from Saccharomyces fragilis and Saccharomyces cerevisiae. Journal of Bacteriology 91, I-I3.

WeInBaum, G., Rich, R. \& Fischman, D. A. (1967). Enzyme-induced formation of spheres from cells and envelopes of Escherichia coli. Journal of Bacteriology 93, 1693-1698.

\section{EXPLANATION OF PLATE}

Electron micrographs of cells fixed in $2 \%(\mathrm{w} / \mathrm{v})$ osmium tetroxide and stained with uranyl acetate or negatively stained with phosphotungstic acid.

Symbols: S, septum; M, mitochondrion; N, nucleus; T, tears in cell wall; Bs, bud scars.

Fig. I. Sectioned cell exhibiting a thin cell wall.

Fig. 2. Sectioned cell exhibiting typical variations of cell-wall thickness. An example of convolution of the inner cell-wall margin is shown in inset.

Fig. 3. Negatively stained sonic oscillator-treated cell exhibiting tears in cell wall but retention of gross structure. 